Original Research Article

\title{
To study the efficacy of non-invasive ventilation in severe bronchiolitis
}

\author{
Thiyagarajan $\mathbf{P}^{1}$, Bala Gopal $\mathbf{M}^{2}$, Ghosh SK ${ }^{3}$, Mihir Sarkar ${ }^{4}$
}

${ }^{1}$ Dr. P. Thiyagarajan, Assistant Professor, ${ }^{2}$ Dr M. Bala Gopal, Associate Professor, both authors are affiliated with Department of Pediatrics, Sri Manakula Vinayagar Medical College and Hospital, Puducherry, India, ${ }^{3}$ Prof (Dr) Sanat Kumar Ghosh, Head of the Department, Department of Paediatrics, Dr. B.C. Roy Post Graduate Institute of Paediatric Sciences, Kolkata, India, ${ }^{4}$ Dr. Mihir Sarkar, Assistant Professor, Department of Pediatrics, Medical College, Kolkata, India.

Address for Correspondence: Dr. P. Thiyagarajan, Email: thiyagumbbs@gmail.com

\begin{abstract}
Objectives: Bronchiolitis is the most common lower respiratory tract infection in infancy and about 6-15\% of patients of acute bronchiolitis require ventilatory support. Non Invasive Ventilation by increasing Mean Airway Pressure reduces airway resistance and recruits non-functional respiratory units to improve oxygenation. The objective of this study is to determine the effectiveness of Non Invasive Ventilation in patients of severe acute bronchiolitis. Methods: The present observational descriptive study was conducted in the department of Paediatrics, Dr. B.C. Roy Post Graduate Institute of Paediatric sciences, Kolkata, India. Those patients fulfilling the criteria for severe Acute Bronchiolitis according to Bronchiolitis Scoring System were included in this study. 76 patients were studied during the 1 year period from April 2014 to March 2015. Results: A success rate of $72.4 \%$ has been observed in this study. Mean duration of Non Invasive Ventilation in patients where it was successful was 32.5 \pm 15.3 hours. Abnormalities in pH and PCO2 improved over a period of 6 hours. Conclusion: Non Invasive Ventilation was found effective in $72.4 \%$ of patients of severe bronchiolitis. Abnormalities in pH \& PCO2 were also improved over 6 hours. Thus, it is an effective, safe and cost effective modality of treatment of severe bronchiolitis.
\end{abstract}

Key words: ABG changes, Bronchiolitis, Efficacy, Non Invasive Ventilation, Success rate

\section{Introduction}

Bronchiolitis is an acute inflammatory respiratory illness of lower respiratory tract of children that occurs in the first 2 years of life and characterized by fever, rhinitis followed by tachypnea, expiratory wheezing, and increased respiratory effort. Bronchiolitis occurs in a seasonal pattern with peak incidence in the winter to spring months. Several viral agents have been identified as etiology of bronchiolitis, like respiratory syncytial virus (RSV), parainfluenza, adenovirus, influenza, and rhinovirus, with RSV being the most prevalent. According to WHO bulletin, an estimated 150 million new cases occur annually. 11-20 million (7-13\%) of these cases are severe enough to require hospital admission. Worldwide, 95\% of all cases occur in developing countries [1]. Thus, bronchiolitis is an important public health problem imposing tremendous burden on the existing medical care facility.

Manuscript received: $7^{\text {th }}$ February 2017

Reviewed: $14^{\text {th }}$ February 2017

Author Corrected: $20^{\text {th }}$ February 2017

Accepted for Publication: 28 ${ }^{\text {th }}$ February 2017
Treatment for bronchiolitis is essentially symptomatic and supportive. With the exception of supportive therapy, including oxygen delivery and mechanical ventilation, there is no scientific evidence to support the use of any treatment $[2,3]$. The main potential benefits of medical assistance in these patients reside in the careful monitoring of clinical status, preservation of the airway opened and cleared of secretions, adequate hydration and oxygenation [4]. Beyond these supportive cares, a considerable portion of patients require ventilatory assistance to maintain adequate ventilation and oxygenation [4-8].

About 6-15\% of patients of acute bronchiolitis require ventilatory support because of the severity of respiratory distress [7,9]. Traditionally Invasive Ventilation is practised. Non Invasive Ventilation (NIV) by increasing Mean Airway Pressure reduces airway resistance and dynamic air trapping. It also recruits many collapsed respiratory units and thereby improves 
ventilation and oxygenation. Besides, NIV has the advantage of allowing the patients a greater degree of autonomy, comfort and less need for sedation. It also avoids the hazards of intubation and its complications namely, ventilator associated infections [5]. Thus, Non Invasive Ventilation should be the preferred mode of ventilator support over invasive mechanical ventilation when ventilatory support is required in cases of severe bronchiolitis.

The aim of this study is to determine the effectiveness of Non Invasive Ventilation in patients of severe bronchiolitis. Major objectives are to study the success rate of NIV, Required mean duration of NIV, ABG changes following successful use of NIV \& to study duration of hospital stay.

\section{Materials and Methods}

The present observational descriptive study was conducted in the department of Paediatrics, Dr. B. C. Roy Post Graduate Institute of Paediatric sciences, Kolkata, India. Those patients were fulfilling the criteria for severe Acute Bronchiolitis according to Bronchiolitis Scoring System (BSS) developed by Dayton Children's Hospital, OH, United States, included in this study [10]. 76 patients of severe bronchiolitis studied during the period from Apr 2014 to Mar 2015. Exclusion criteria are Children with congenital heart diseases, congestive cardiac failure; congenital anomalies involving thorax (Congenital Diaphragmatic Hernia, Eventration of diaphragm and sequestration of lung), respiratory diseases other than bronchiolitis, oro-facial anomalies, ascites or any gastro intestinal diseases interfering with normal ventilation, Failure To Thrive and Protein Energy Malnutrition.
All the cases of severe bronchiolitis according to BSS were administered NIV along with other supportive management. Before instituting NIV support, Arterial Blood Gas (ABG) analysis done for all these patients to look for $\mathrm{pH}, \mathrm{PO} 2, \mathrm{PCO} 2, \mathrm{HCO}$, Base Excess (BE) using OPTI-CCA cassette. NIV support has been provided through Fisher \& Paykel bubble CPAP system. NIV support delivered via appropriate size nasal cannula / nasal mask. After instituting NIV, OroGastric tube has been put to decompress the stomach and prevent chances of aspiration.

An initial PEEP of $4 \mathrm{cmH} 2 \mathrm{O}$ and initial $\mathrm{FiO} 2$ of $40 \%$ has been used and progressively increased by $1 \mathrm{cmH} 2 \mathrm{O}$ and $5 \%$ respectively at a time with monitoring of the patient to keep work of breathing minimal and to maintain saturation in the normal range (93-97\%). Once the child has been put under NIV support, patient has been monitored every 30minutes-1 hourly for Level of Consciousness, adequacy of ventilation by doing BSS score, circulatory status (Temperature, Heart Rate, Blood Pressure, CRT, Urine Output), and monitored for any other complications during the course of treatment. ABG monitoring is done serially, every 2 hours until the correction of ABG and then every 12 hourly till the NIV support weaned. Once the work of breathing decreased, maintaining SpO2, level of PEEP \& percentage of $\mathrm{FiO} 2$ has been decreased successively till it reaches the minimum value that can maintain normal oxygenation and ventilation $[8,12]$. If the $\mathrm{SpO} 2$ could not be maintained using a PEEP of $7 \mathrm{cmH} 2 \mathrm{O}$ and $\mathrm{FiO} 2$ of $70 \%$ or the BSS score and ABG deteriorate or same after 6 hours of instituting NIV, these patients are categorised as NIV failed cases and treated with intubation and Invasive Mechanical Ventilation initiated without any delay.

\section{Results}

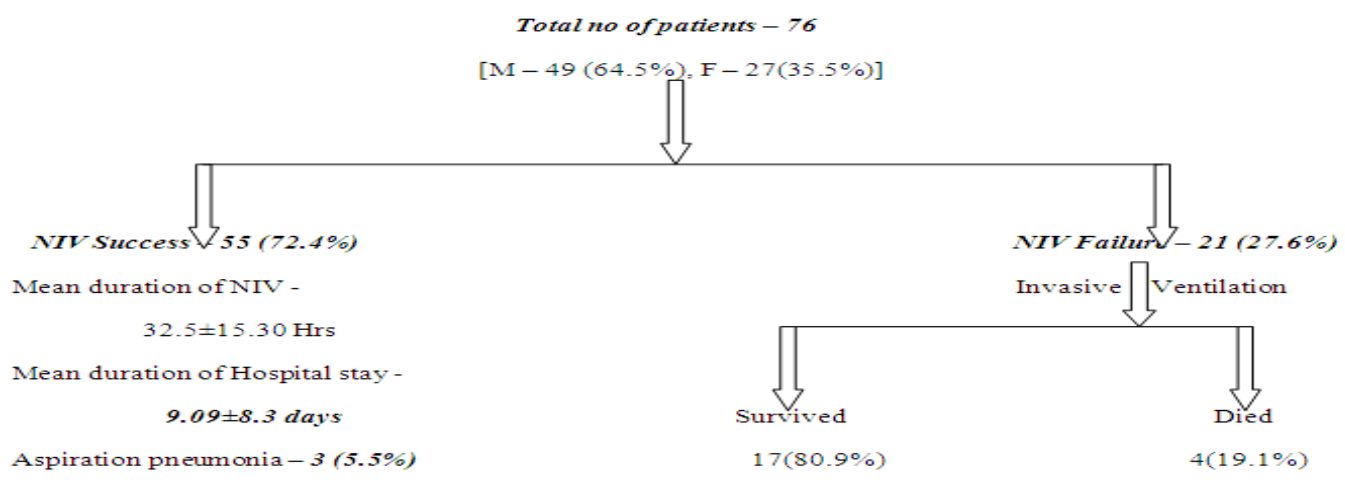

Mean duration of Hospital stay

$15.33 \pm 1.67$ days 
Out of the total 76 patients studied, 55 patients improved with NIV alone. 21 patients required invasive ventilation. $72.4 \%$ success rate has been observed in this study. The Z-Score was 5.5155 . The p-value was $<0.05$ which was statistically significant. Aspiration pneumonia was the lone complication observed in 3 NIV successful patients (5.5\%). Out of the 21 NIV failure patients, 17 patients improved with Invasive Mechanical Ventilation. Another 4 patients died mostly due to sepsis and its complications.

Table-1: Demographic characters, Initial SpO2 in room air \& required PEEP of study population.

\begin{tabular}{|c|c|c|}
\hline & NIV success (n-55) & NIV failure (n-21) \\
\hline \multicolumn{3}{|l|}{ 1. Age } \\
\hline$\leq 3$ months & $23(42.0 \%)$ & $09(42.8 \%)$ \\
\hline $3-6$ months & $19(34.5 \%)$ & $06(28.6 \%)$ \\
\hline $6-12$ months & $08(14.5 \%)$ & $06(28.6 \%)$ \\
\hline$>12$ months & $05(9.0 \%)$ & $00(0.0 \%)$ \\
\hline Median age & $150.9091 \pm 117.507$ days & $147.81 \pm 92.503$ days \\
\hline \multicolumn{3}{|l|}{$2 . \operatorname{Sex}$} \\
\hline Male & $37(67.2 \%)$ & $12(57.1 \%)$ \\
\hline Female & $18(32.8 \%)$ & $09(42.9 \%)$ \\
\hline \multicolumn{3}{|c|}{ 3.Initial SPO2 in room air $(\%)$} \\
\hline$\leq 80$ & $08(14.5 \%)$ & $05(23.8 \%)$ \\
\hline $81-82$ & $09(16.3 \%)$ & $07(33.4 \%)$ \\
\hline $83-84$ & $06(11.0 \%)$ & $04(19.0 \%)$ \\
\hline $85-86$ & $18(32.7 \%)$ & $04(19.0 \%)$ \\
\hline $87-88$ & $08(14.5 \%)$ & $01(4.8 \%)$ \\
\hline $89-90$ & $06(11.0 \%)$ & $00(0.0 \%)$ \\
\hline \multicolumn{3}{|c|}{ 4.Required PEEP (cmH2O) } \\
\hline 5 & $06(11.0 \%)$ & $00(0.0 \%)$ \\
\hline 6 & $36(65.4 \%)$ & $12(57.1 \%)$ \\
\hline 7 & $13(23.6 \%)$ & $09(42.9 \%)$ \\
\hline
\end{tabular}

In studying the required duration of NIV support to the patients of severe acute Bronchiolitis, majority of patients $(63.6 \%)$ required duration of 37-48 hours (Table-2). The Z-Score was 3.8297. The p-value was 0.00012 which was statistically significant. Mean duration of NIV in our study was $32.5 \pm 15.30$ hours.

Table-2: Duration of NIV (Hrs) in patients where it was successful.

\begin{tabular}{|c|c|c|}
\hline Duration of NIV(Hrs) & Frequency & Percentage \\
\hline$\leq 6$ & 0 & $0.0 \%$ \\
\hline $7-12$ & 2 & $3.6 \%$ \\
\hline $13-24$ & 3 & $5.5 \%$ \\
\hline $25-36$ & 15 & $27.3 \%$ \\
\hline $37-48$ & 35 & $63.6 \%$ \\
\hline Total & $\mathbf{5 5}$ & $\mathbf{1 0 0 . 0} \%$ \\
\hline
\end{tabular}

Requirement of PEEP depends on the severity of respiratory distress in severe acute bronchiolitis. Minimum required PEEP of $5 \mathrm{cmH} 2 \mathrm{O}$ [n- $6(7.9 \%)]$ and maximum required PEEP of $7 \mathrm{cmH} 2 \mathrm{O}$ [n- $22(28.9 \%)$ ] have been observed in this study. Majority of patients [n-48 (63.2\%)] required a PEEP of $6 \mathrm{cmH} 2 \mathrm{O}$. The Z-Score was 7.1181. The p-value was $<0.05$ which was statistically significant. 
Mean $\mathrm{pH}$ at the time of admission in this study was $7.37 \pm 0.25$. Mean $\mathrm{pH}$ after $6 \mathrm{hrs}$ in the present study was $7.40 \pm 0.26$. There was an improvement in $\mathrm{pH}$ after 6 hours of NIV (Fig -1$)$. The p-value was $<0.00001$. The result was significant at $\mathrm{p}<.05$.

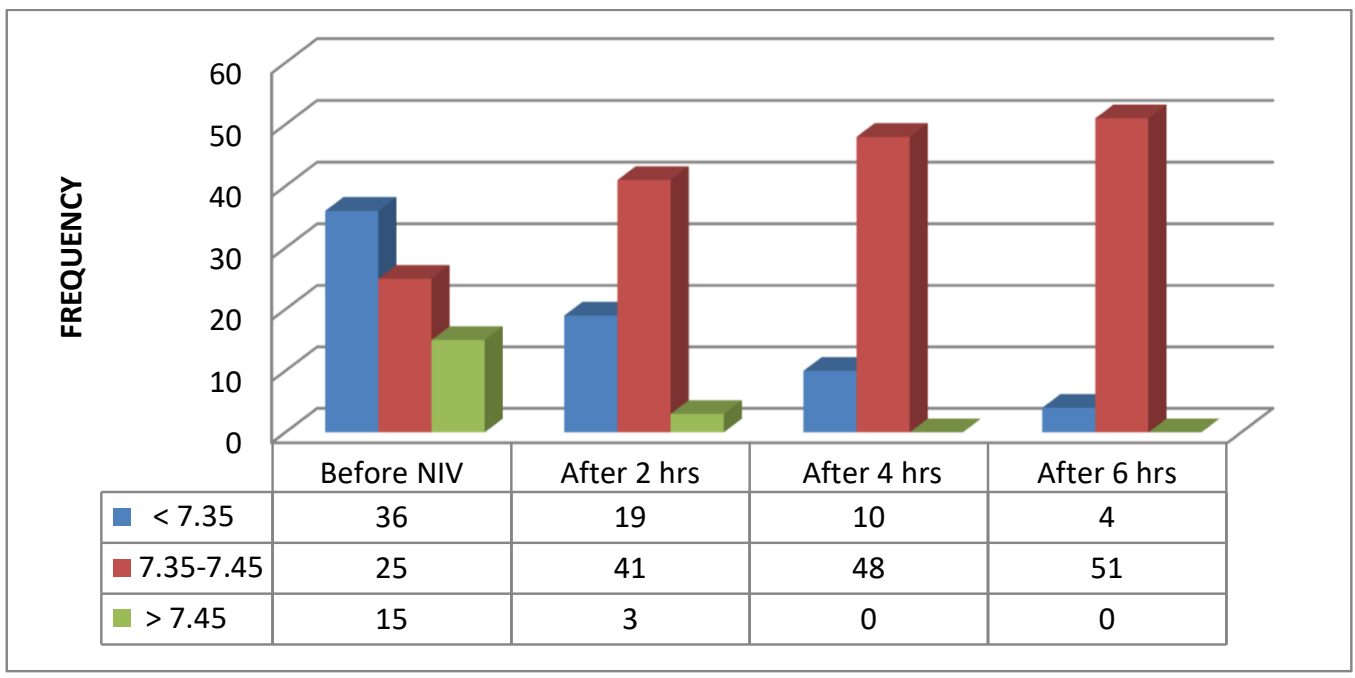

Fig-1: Changes in pH following successful use of NIV

Mean PCO2 at the time of admission before instituting NIV in the present study was $39.64 \pm 13.34 \mathrm{mmHg}$. Mean PCO2 after $6 \mathrm{hrs}$ in the study population was $38.96 \pm 10.21 \mathrm{mmHg}$. There was normalization of PCO2 after 6 hours of NIV (Fig -2). The $\mathrm{p}$-value was $<0.00001$. The result was significant at $\mathrm{p}<.05$.

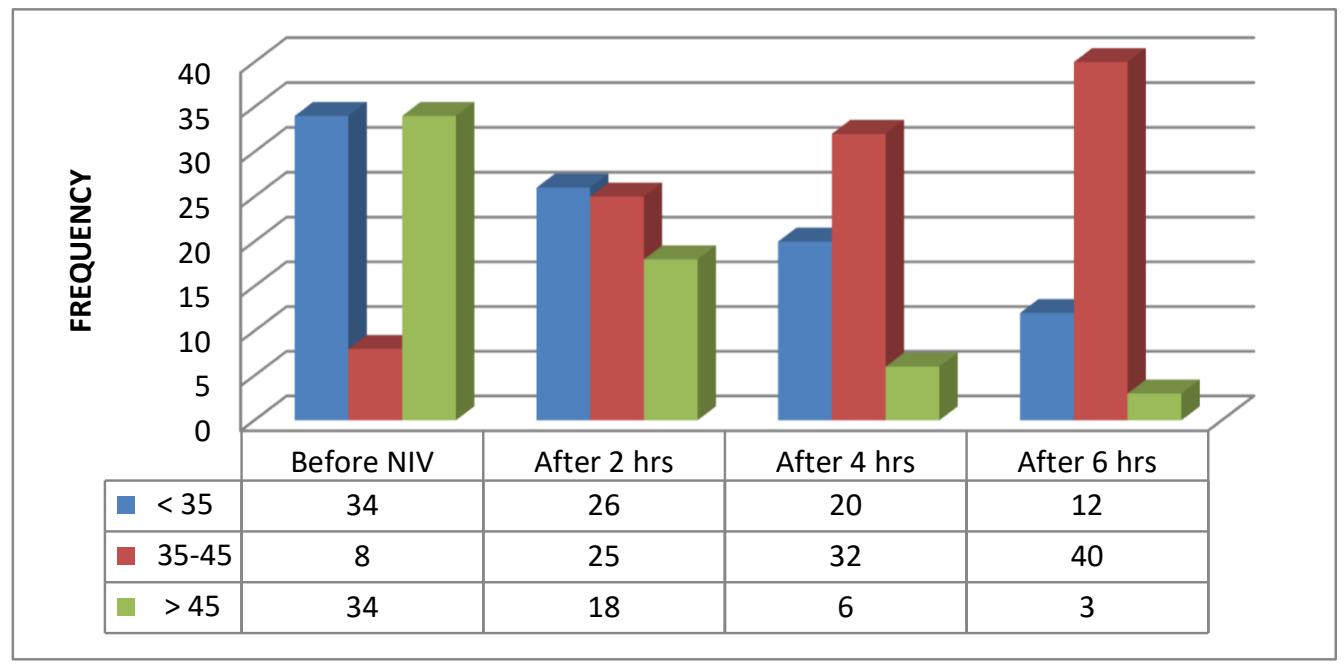

Fig-2: Changes in PCO2 following successful use of NIV

\section{Discussion}

Bronchiolitis is an acute inflammatory respiratory illness of lower respiratory tract of children that occurs in the first 2 years of life. Pathophysiologically, bronchiolitis is an infection of the bronchiolar epithelium, with subsequent profound sub-mucosal and adventitial edema, increased secretion of mucus, peribronchiolar mononuclear infiltration, and epithelial cell necrosis \& sloughing which leads to airway obstruction. The complete plugging of some airways and partial plugging of others may lead to localized atelectasis and over distention respectively. These results in ventilation-perfusion mismatch causing hypoxemia which requires supportive oxygen therapy [3]. 
Treatment for bronchiolitis is essentially symptomatic and supportive. Despite the high prevalence and morbidity of bronchiolitis, therapy remains controversial. Humid atmosphere, adequate fluids, antipyretics, oxygen are main stay of therapy. Antibiotics have no role since it is a viral disease with minimal chance of secondary bacterial infection. Use of bronchodilators (both adrenergic and anti cholinergics) remain controversial.

Therefore, treatment options for bronchiolitis are scant. With the exception of supportive therapy, including oxygen delivery and mechanical ventilation, there is no scientific evidence to support the use of any treatment. The main potential benefits of medical assistance in these patients reside in the careful monitoring of clinical status, preservation of the airway opened and cleared of secretions, adequate hydration and oxygenation [4]. Beyond this supportive care, a considerable portion of patients require ventilatory assistance to maintain adequate ventilation and oxygenation [4-8].

In recent years, non-invasive ventilation (NIV) has become an important alternative to respiratory support treatment for children with acute respiratory failure. In theory, the use of NIV in respiratory failure allows for the recruitment of collapsed or non-ventilated alveoli, increases the functional residual capacity, improves the ventilation/perfusion ratio, optimizes respiratory dynamics, reduces the work of breathing and improves gas exchange [6].

A number of studies are recently conducted on the efficacy of Non Invasive Ventilation as an intervention to give respiratpory support in acute bronchiolitis [4-7]. The success rate of Non Invasive Ventilation reported in literature is $70-80 \%$ [7,9]. The volume of literature on this subject is still scanty and thus the present study is undertaken to find the effectiveness of Non Invasive Ventilation in patients of acute bronchiolitis who will be requiring ventilatory support.

Since Non Invasive Ventilation, helps by keeping the airway patent, recruiting more and more respiratory units of the lung, diminishing work of breathing and improving oxygenation, it should be effective in acute bronchiolitis. If Non Invasive Ventilation is effective in improving ventilation and oxygenation in acute bronchiolitis, this mode of ventilation would be preferred over invasive mechanical ventilation for its less invasiveness.
In the present study, out of the 76 patients studied, most of the patients $(75 \%)$ requiring Non-Invasive Ventilatory support for severe acute bronchiolitis were infants less than 6 months (Table-1). Nizarali $Z$ et al. in their study observed $100 \%$ patients requiring NIV were less than 6 months [7]. Nune's P et al. observed that $82.7 \%$ of patients requiring NIV were less than 6 months of age [12].

In this study, $64.5 \%$ were males and $35.5 \%$ were females (Table-1). This explains that male patients of severe acute bronchiolitis required Non-Invasive Support were more in number statistically than their female counterparts. Findings observed from studies done by Campion A et al. (57.4\%) [11], Nizarali Z et al. (53.7\%) [7], Nune's $P$ et al. (51.7\%)[12] are corroborative with the present study.

Lazner M R et al. found that NIV was effective in $80 \%$ of infants receiving respiratory support for severe bronchiolitis[9]. Campion A et al. conducted a study to evaluate the feasibility of NIV in infants with severe infection presumably due to RSV, which showed 68\% success rate of NIV [11].

Nune's $\mathrm{P}$ et al. observed the mean duration of NIV in their study was $47.7 \pm 35.6$ hours [12] which are similar to the result of our study. Jennifer $\mathrm{M}$ et al. observed the mean duration of NIV in their study was 5.2 days [13] and Essouri $\mathrm{S}$ et al. found a mean duration of $4.1 \pm 3.5$ days [14]. This difference is explained by inclusion of more number of severe cases of acute bronchiolitis included in our study.

Milesi $\mathrm{C}$ et al. showed that the use of initial PEEP of $6 \mathrm{cmH} 2 \mathrm{O}$ rapidly decreased the inspiratory work in young infants with acute bronchiolitis [15]. Improvement in the respiratory distress score at 6 hour was proportional to the initial clinical severity suggesting the importance of rapid CPAP initiation in the more severe forms of disease [15]. Study done by Essouri $\mathrm{S}$ et al. showed that use of $7 \mathrm{cmH} 2 \mathrm{O}$ associated with greatest unloading of the respiratory muscles in severe acute bronchiolitis[16]. In our study, $28.9 \%$ of patients of severe acute bronchiolitis required a PEEP of $7 \mathrm{cmH} 2 \mathrm{O}$.

Nune's P et al. observed that, no major complications associated with the use of NIV [12]. One patient developed pneumothorax following NIV support for severe acute bronchiolitis in a study done by Jennifer M et al [13]. Fleming PF et al. found that, no adverse 
effects was seen when CPAP was used during stabilisation \& transport of acute bronchiolitis patients to a tertiary centre in their study [17].

Javouhey E et al. did a retrospective study on NIV as primary ventilator support for infants with severe bronchiolitis proved that no Ventilator Associated Pneumonia (VAP) has been observed during the course of NIV support [18]. No complications have also been observed during the course of CPAP in a study conducted by Thia LP et al [19].

Campion A et al. observed rise in $\mathrm{pH}$ within 2 hours NIV [11]. Soong W J et al. observed that mean rise in $\mathrm{pH}$ from 7.33 to 7.37 after 2 hours of NIV [20]. Bardsen $\mathrm{K}$ et al. observed that there was a significant decline in median PCO2 after 4 hours [21]. Campion A et al. observed fall in PCO2 within 2 hours of NIV support [11]. Jennifer $M$ et al. showed in their study that mean fall in PCO2 from 59.0 to $47.4 \mathrm{mmHg}$ over the initial 3 hours of NIV [14]. Larrar S et al. observed in their study that mean fall of $\mathrm{PCO} 2$ from $64.3 \pm 13.8$ to $52.6 \pm 11.7 \mathrm{mmHg}[22]$.

\section{Conclusion}

Non Invasive Ventilation was found effective in $72.4 \%$ of patients of severe bronchiolitis. There is an improvement of $\mathrm{pH}$ and correction of $\mathrm{PCO} 2$ following the use of NIV. Complications of NIV are uncommon except a small portion of the patients developed aspiration pneumonia. Thus, NIV is an effective, safe and cost effective modality of treatment of severe bronchiolitis.

NIV is to be preferred to Invasive Mechanical Ventilation which is to be used only in NIV failed cases of severe bronchiolitis. As our study sample is smaller (i.e 76 patients) and the period of study also has been shorter (i.e 1 year), we can't draw a generalized conclusion to apply on a large scale basis. More studies are to be conducted from multiple centres and Meta analyses of all those studies are required for general recommendation of the conclusion of the present study.

Funding: Nil, Conflict of interest: None initiated, Perission from IRB: Yes

\section{References}

1. Rudan I et al. Global estimate of the incidence of clinical pneumonia among children under five years of age. Bull World Health Organ. 2004 Dec. 82(12):895903.
2. Paul VK, Bagga A, editors. Ghai Essential Pediatrics. 8th ed. NewDelhi:CBS Publishers \& Distributors pvt Ltd;2013. Chapter 14, Disorders of Respiratory system; p.381-82.

3. Parthasarathy A, Menon PSN, Kundu R, editors. IAP Textbook of Pediatrics. $6^{\text {th }}$ ed. NewDelhi:Jaypee Brothers Medical Publishers (p) Ltd;2013.Chapter 8.7, Bronchiolitis; p.565-68.

4. Martinón-Torres F. Current treatment for acute viral bronchiolitis in infants. Expert Opin Pharmacother. 2003 Aug;4(8):1355-71

5. Kissoon N, Adderley R. Noninvasive ventilation in infants and children. Minerva Pediatr. 2008 Apr; 60(2):211-8.

6. Gregoretti C, Pelosi P, Chidini G, Bignamini E, Calderini E. Non-invasive ventilation in pediatric intensive care. Minerva Pediatr. 2010 Oct;62(5): 437-58

7. Nizarali $Z$ et al. Noninvasive ventilation in acute respiratory failure from respiratory syncytial virus bronchiolitis. Rev Bras TerIntensiva2012 Dec; 24 (4): 375-380.

8. Teague WG. Noninvasive ventilation in the pediatric intensive care unit for children with acute respiratory failure. Pediatr Pulmonol. 2003 Jun; 35 (6): 418-26.

9. Lazner MR, Basu AP, Klonin H. Non-invasive ventilation for severe bronchiolitis: analysis and evidence. Pediatr Pulmonol. 2012 Sep;47(9):909-16. doi: 10.1002/ppul.22513. Epub 2012 Feb 10.

10. Bronchiolitis- Clinical Practise Guidelines [Internet]. [cited 5 January 2017]. Available from: http://www.childrensdayton.org/cms/sitelet/e2f0864ef2 25ca51/index.html

11. Campion A et al. Non-invasive ventilation in infants with severe infection presumably due to respiratory syncytial virus: feasibility and failure criteria. Arch Pediatr. 2006 Nov;13(11):1404-9.

12. Nunes P, Abadesso C, Almeida E, Silvestre C, Loureiro $\mathrm{H}$, Almeida $\mathrm{H}$. [Non invasive ventilation in a pediatric intensive care unit]. Acta Med Port. 2010 May-Jun;23(3):399-404. Epub 2010 Jun 14. 
13. Beasley JM, Jones SE. Continuous positive airway pressure in bronchiolitis. Br Med J (Clin Res Ed). 1981 Dec 5;283(6305):1506-8.

14. Essouri $\mathrm{S}$ et al. Improved clinical and economic outcomes in severe bronchiolitis with pre-emptive nCPAP ventilatory strategy. Intensive Care Med. 2014 Jan;40(1):84-91.

15. Milési C, Matecki S, Jaber S, Mura T, Jacquot A, Pidoux O, Chautemps N, Novais AR, Combes C, Picaud JC, Cambonie G. $6 \mathrm{cmH} 2 \mathrm{O}$ continuous positive airway pressure versus conventional oxygen therapy in severe viral bronchiolitis: a randomized trial. Pediatr Pulmonol. 2013 Jan; 48(1): 45-51. doi: 10. 1002/ppul. 22533. Epub 2012 Mar 19.

16. Essouri $\mathrm{S}$ et al. Optimal level of nasal continuous positive airway pressure in severe viral bronchiolitis. Intensive Care Med. 2011 Dec;37(12):2002-7.

17. Fleming PF, Richards S, Waterman K, Davis PG, Kamlin CO, Sokol J, Stewart M. Use of continuous positive airway pressure during stabilisation and retrieval of infants with suspected bronchiolitis. J Paediatr Child Health. 2012 Dec;48(12):1071-5. doi: 10.1111/j.1440-1754.2012.02468.x. Epub 2012 May 15.
18. Javouhey E, Barats A, Richard N, Stamm D, Floret D. Non-invasive ventilation as primary ventilatory support for infants with severe bronchiolitis. Intensive Care Med. 2008 Sep;34(9):1608-14. doi: 10.1007/ s00134-008-1150-4. Epub 2008 May 24.

19. Thia LP, McKenzie SA, Blyth TP, Minasian CC, Kozlowska WJ, Carr SB. Randomised controlled trial of nasal continuous positive airways pressure (CPAP) in bronchiolitis. Arch Dis Child. 2008 Jan; 93(1):45-7. Epub 2007 Mar 7.

20. Soong WJ, Hwang B,Tang RB. Continuous positive airway pressure by nasal prongs in bronchiolitis. Pediatr Pulmonol. 1993 Sep;16(3):163-6.

21. Oymar K, Bårdsen K. Continuous positive airway pressure for bronchiolitis in a general paediatric ward; a feasibility study. BMC Pediatr. 2014 May 12;14:122. doi: 10.1186/1471-2431-14-122.

22. Larrar S, Essouri S, Durand P, Chevret L, Haas V, Chabernaud JL, Leyronnas D, Devictor D. Effects of nasal continuous positive airway pressure ventilation in infants with severe acute bronchiolitis. Arch Pediatr. 2006 Nov;13(11):1397-403. Epub 2006 Sep 7.

\section{How to cite this article?}

Thiyagarajan P, Bala Gopal M, Ghosh SK, Mihir Sarkar. To study the efficacy of non-invasive ventilation in severe bronchiolitis. J PediatrRes.2017;4(02):106-112.doi:10.17511/ijpr.2017.i02.03. 